\title{
Kurdistan: The Taiwan of the Middle East?
}

\author{
Yvonne Chiu ${ }^{1}$
}

Published online: 13 June 2018

(C) Springer Science+Business Media, LLC, part of Springer Nature 2018

\begin{abstract}
Taiwan and Kurdistan appear to have little in common, but the progressive values of these two societies embedded within hostile regions make them both natural allies and important strategic assets in the U.S.'s and international community's long-term fight against authoritarianism and radical religious theocracies. Instead, they have been ignored and/or exploited in the pursuit of shortterm geopolitical and economic interests in the Asia-Pacific and Middle East regions, which comes at great cost to American and international values as well as long-term strategic interests, so both citizens and policymakers must consider new approaches.
\end{abstract}

Keywords China $\cdot$ Taiwan $\cdot$ Middle East $\cdot$ Kurds $\cdot$ Foreign policy $\cdot$ International community $\cdot$ Geopolitics

Over the past half century, what is now nine American administrations have faced intractable geopolitical conflicts in which they appeased dominant regional powers at the expense of smaller ones more aligned with progressive values and international norms. The same trade-off is made in radically different regions. In East Asia, Taiwan - a thriving liberal democracy - is sidelined, while in the Middle East, the Kurdish people, who form a progressive Muslim society, lack any feasible path toward independent statehood. Despite their differences, recognizing the structural similarities between Taiwan and Kurdistan allows for both citizens and policymakers to hold more comprehensive policy debates about these situations.

In both cases, American cultivation of immediate geopolitical and economic goals has come at great cost to its own values as well as its own long-term strategic interests. Intellectuals and policymakers justify this by imagining that the powers they favored (e.g., China, Saudi Arabia) could be managed according to American ambitions and would become more moderate with time, engagement, and rising incomes; that has not been the case, and it is foolhardy to believe that moderation might still transpire this way.

These false narratives about the dominant regional powers harm the entire international community, although

Yvonne Chiu

yvonne.chiu@amias.ias.edu

1 School of Social Science, Institute for Advanced Study, 1 Einstein Drive, Princeton, NJ 08540, USA that is partly well-intentioned. In the face of geopolitical uncertainty, Western politicians, academics, and intelligentsia search for familiar interlocutors among unfamiliar adversaries, in particular for a liberal democratic Confucianism and a moderate Islam, but they have focused their attention in the wrong places, much to their own detriment.

\section{The Quest for a Liberal Democratic Confucianism}

To the East, people scour China's landscape for signs of influence from traditional philosophies such as Confucianism and classical Chinese military ethics, which are perceived as ruleabiding, moral, and meritocratic. They hope it will shed light on contemporary Chinese thinking, and that the moral rectitude emphasized therein indicates that China and its military will respect the rule of law, human rights, civil liberties, and international law.

That optimism is, unfortunately, misguided. Historical Chinese thought actually reveals little about its contemporary counterpart, because the major Chinese cultural traditions (both thoughts and practices) were thoroughly purged by the Communist Party over the past seventy years, through a series of horrific upheavals and manmade tragedies.

Some scholars are developing contemporary Chinese political and military ethics by drawing from and reconstituting traditional schools of thought, but these philosophies are not 
significant in contemporary Chinese society or People's Liberation Army (PLA) military ethics, as is frequently believed. This misunderstanding is encouraged by the CCP itself: it erected (then removed) Confucius's statue in Tiananmen Square, and touts its "Confucian" study groups, its carefully-named Confucius Institutes across the world, and the teaching of the Seven Military Classics at its military academies. Observers usually take this at face value and believe that this means ordinary Chinese people are re-integrating Confucianism into their lives.

What they and even Chinese people themselves miss is that the "Confucian revival" is more apparent than real, as most Chinese readers can access only censored excerpts of Confucius's writings or approved interpretations that emphasize obedience and filial piety (to the Party) and omit the passages about governors' duties to rule sagely and serve the interests of the people. (Most observers and Chinese alike also seem to forget the richness and variety of Chinese political thought beyond Confucianism, including Mohism, Daoism, Legalism, and Buddhism, among others.) This state-sanctioned "Confucianism" is stripped of its complexity, substituting instead simplistic conceptions of hierarchy that suit the Party's purposes. In reality, it is authoritarianism masquerading under the recognizable brand of Confucius' name.

Furthermore, the CCP itself is simultaneously forthcoming on these matters. The PLA's contemporary writings on military ethics focus primarily on the ethical imperative of self- sacrifice for Party and country, rather than the urgency of the ruler's own moral uprightness in waging war (as discussed throughout the Seven Military Classics) or the principles of civilian immunity, POW protections, and other widely-accepted tenets of the Geneva Conventions on the laws of war. China alternately advocates economic development and growth as paramount human rights and scolds the rest of the world that what happens in China is none of their business and that they should look to their own sins. Alongside talk of a "harmonious" society and "peaceful rise," sanctioned Chinese political thought presents war as "not only a military struggle, but also a comprehensive contest on fronts of politics, economy, diplomacy, and law," and considers international law "a powerful weapon to expose the enemy and win over sympathy and support of the international community and strive to gain the position of strategic initiative."

China's own statements combined with its ongoing aggressiveness in the Asia-Pacific region-including the East and South China Seas, where China's territorial expansion through building artificial islands is unsettling the region-demonstrate that what the international community seeks is not to be found there.

\section{The Taiwan Model}

Most of all, the international community willfully overlooks that everything it is searching for already exists - conveniently-right across the strait. Taiwan's modern society is deeplyinfluenced by traditional Chinese values, and is now nearly unrecognizable from its authoritarian days, having nonviolently transformed from an oppressive dictatorship (that ruled with martial law until 1987) to a successful liberal democracy. Is that democracy sometimes messy, raucous, petty, and corrupt? Absolutely. But it is also vibrant, diverse, complex, open, stable, and, most importantly, willing to confront its difficult past and inevitable present shortcomings, as only sincere liberal democracies do. More so than any other country in Asia, Taiwan has attempted to rectify past injustices against indigenous groups, for example, and its high court has boldly paved the way for the legalization of gay marriage, which would make it the vanguard in Asia. All this is a remarkable achievement in less than three decades.

China's rapid modernization notwithstanding, the CCP's chosen path is decidedly illiberal and oppressive. Modernity alone cannot induce freedom, autonomy, and protections of basic rights and liberties, as the lessons of twentieth-century totalitarianism have already shown. Despite its stunning economic growth in the recent decades, China shows no signs of establishing genuine rule of law, separation of powers, constitutionalism, an independent judiciary, and essential rights protections - all of which already exist in Taiwan.

Yet, the international community is only too eager to go along with China's "one-China" policy and its designation of Taiwan as a renegade province; as of this writing, all states save seventeen (plus the Vatican) refuse to recognize Taiwan as a country. Multiple American administrations have held Taiwan out as a bargaining chip in an effort to appease China, most recently the Trump administration on the heels of a controversial phone call from Taiwan's president Tsai Ingwen to the newly-elected American president that would have been utterly unremarkable between any two other countries.

The international community excuses this diplomatic purgatory by pointing to Taiwan's "de facto" or "effective" independence - but it is not independence if it exists only at the will and whim of a more powerful actor and can be revoked at any time without recourse. Some cite surveys in which a majority of Taiwanese favor the status quo of international limbo over reunification or declaring independence, but these surveys fail to ask about the impact on their preferences of China's direct and frequent threats, regular interference in Taiwanese elections, and roughly 1500 missiles aimed at Taiwan at all times. (More comprehensive surveys show that a majority of even the more-conciliatory KMT supporters actually still would not prefer even peaceful reunification.) China considers Taiwan a "core interest," but accepting that claim at face value means endorsing both ethnic essentialism 
and the recently-spun fiction of a long- united China only seeking to reclaim its territory: it blatantly disregards both historical reality and the wishes of the majority of liberaldemocratic Taiwan's 23 million people.

Furthermore, lack of formal diplomatic recognition and the international rights and privileges therein actually does enormous harm. China's interference ranges from petty (e.g., forcing suspension of the Kimberley Process, an intergovernmental meeting on stemming "blood diamond" trade, until Taiwanese observers were ejected, or threatening punishment against international airlines that list Taiwan separately) to debilitating (e.g., limiting economic development by pressuring other countries to not sign trade agreements with Taiwan, persuading countries such as Spain and Kenya to extradite suspected Taiwanese criminals to China instead) to downright dangerous (e.g., "oneChina" excludes Taiwan from membership in international organizations, so the WHO knowingly jeopardized millions of lives during the 2003 SARS epidemic by refusing to share vital information or cooperate with or send assistance to Taiwan until it received Chinese permission, which came only after SARS had already spread rapidly.)

Yet the international community turns a blind eye, instead strategically currying favor with the larger economy and greater military power. While the U.S. Congress's Taiwan Relations Act formally agrees to sell arms to Taiwan for defensive purposes, it is ambiguous about the nature of its requirement to defend Taiwan in the event of Chinese attack, and the U.S. signals its ambivalence and pressures Taiwan into not rocking the boat, by holding back on weapons sales and visa privileges, for example.

\section{The Self-Sabotage of Pursuing Stability}

Accepting the "one-China" policy — and in effect China's claim over Taiwan - is problematic for at least two reasons. First, all liberal-democratic societies acquiescing to this damage their own domestic interests. While international sponsorship of one's domestic rights and values is not required in a Westphalian-based system of sovereign states or in many theories of political ethics, the strength of those domestic principles is called into question when they are blatantly disregarded by the same actors overseas. It is the burden of universalistic theories to be held to a higher standard.

Second, the international community must encourage and incentivize in China what has already happened in Taiwanbut it is a grave mistake to think that it can do so by shunting aside the very model of Confucian liberalism it wants to promote, and instead short-sightedly catering to illiberal and aggressive Chinese demands.

Geopolitical interests in accessing China's market and resources as well as taming a potential adversary and preventing war are crucial, but pursuing them this way will not incentivize the CCP to cooperate, for it assumes that China's intentions are limited and that appeasement will work. There is little evidence of the former. As for the latter, maintaining the status quo or offering concessions in the form of a "grand bargain" involving Taiwan does the opposite, as the CCP already takes the international community's willingness to sacrifice its own values for the sake of stability, "harmony," and economic growth - which happens to align with China's stated mōrēs - as an indication that there is no need to reform or cooperate, as it is already getting what it wants by sheer dint of potential power.

\section{An Elusive Kurdistan}

On the other side of the world, the nation of Kurdistan, which exists only in the imagination, is similarly situated. The differences are obvious, as Taiwan is an established, if unrecognized, country with defined boundaries, whereas Kurdistansemi-autonomous Kurdistan Region in Iraq notwithstanding - is a collection of people spread across territories in Turkey, Syria, Iraq, and Iran, and not politically organized or unified to nearly the same extent. Nonetheless, there is a crucial parallel: its tenuous situation within a larger hostile environment, despite its greater alignment with American and international political and social values.

The Kurds live among hardline regimes that promote extreme interpretations of Islam largely indistinguishable from that of ISIS in order to stay in power. (Countries do so differently: e.g., Saudi Arabia's dominant religious sect and official government ally is Wahhabism, whose beliefs are no more enlightened than ISIS's, all the way down to public beheadings, executing "witches," and stoning adulterers. Meanwhile, Syria's secular nationalist Baathist regime has an unofficial marriage of convenience with and likely provides arms to ISIS, to fan the flames of sectarianism on which the government then cracks down, in order to justify its own oppressive rule.)

In the midst of strongly patriarchal societies that legalize all manner of restrictions on women's movement, education, marriage, and access to services, afford them few rights to property or their own bodies even in cases of horrific abuse, and turn a blind eye to honor killings and rapes, one of the most notable Kurdish innovations is gender egalitarianism. The pro-Kurdish H.D.P. party in Turkey decrees that men in polygamous marriages or who had been convicted of abuse cannot run for office or hold party positions, all parliamentary tickets must be gender-balanced, Kurdish towns must have male and female co-mayors, local government boards and committees must include female co-executives, women must be hired in new patronage and municipal jobs until there is gender balance, decisions about women (handled by the Women's Affairs Department) must be made by women, wives can receive monetary compensation from abusive 
husbands, and guerrilla units must be fully gender-integrated, including their command positions. Similar protections exist in other Kurdish-governed areas.

Yet, even in officially — but increasingly tenuously — secular Turkey, this progressive incarnation of Muslim society is under assault, with its leaders jailed on political grounds, and the H.D.P.'s sister party P.K.K. banned and deemed a terrorist organization by Turkey, the U.S., and Europe. Kurdish society is far from perfect - many struggle with gender equality privately and in practice, and there are problems with corruption - but it is a more liberal and tolerant form of Islam, and a beacon in an otherwise bleak and violent ocean.

Despite a brief flirtation with the idea of a Kurdistan region after the Ottoman Empire's collapse and the existing Kurdish Autonomous Region in Iraq (which on 26 September 2017 voted overwhelmingly in a referendum in favor of independence, in the face of concerted opposition from the United Nations, U.S., Turkey, Iraq, and Iran, and military threats by some of those neighbors), much of Kurdish history has been of rebellions, uprisings, and violent repression, and with little serious movement toward a greater independent Kurdistan.

Meanwhile, Kurds occupy the frontlines of several wars against more oppressive regimes (including the 1991 Gulf War, the ongoing Syrian civil war, and the fight against ISIS) as sacrificial pawns: sent into the fray, but when they win too many battles and advance too far forward, those ostensibly on the same side but opposed to an independent Kurdistan (e.g., Turkey, Syria, Russia, etc.) turn to attack the Kurds instead, as they prefer oppressive and murderous Islamists to progressive ones that might ultimately threaten their own rule.

While the U.S. provides material and military support to the Kurds, including some combat troops, it is insufficient and largely behind-the-scenes, because the U.S. needs access to Incirlik $\mathrm{AB}$ and other regional facilities from Turkey, a fellow NATO member. Separately, the U.S. continues to tout its alliance with hardline theocracy Saudi Arabia, for example, while the international community also perpetuates Saudi Arabia's good standing - sometimes in farcical ways, such as with its appointment to the United Nations' Commission on the Status of Women.

This causes similar long-term problems as the lack of endorsement for Taiwan. There should be no equivocation about American and international backing for a moderate Muslim society: this ambivalence only undermines their own values, and further promotes the very type of Islam that they are fighting against. As such, the Kurds are stuck in a comparable place: a people with values rare in their region and who should be arduously promoted, but is instead exploited in favor of alliances with larger authoritarian and/or religious-extremist regimes.

\section{Possible Room for Maneuver}

In both cases, liberal democratic citizens of all political leanings should advocate formal independence for both Taiwan and Kurdistan. It is a radical position — but the correct oneand they should promote this even as they recognize that it is an unlikely outcome.

What is more likely, and what American foreign policymakers should push for is more autonomous regions for the Kurdish populations in their respective territories and greater formal integration of Taiwan into the international community. While adversaries should not be provoked into aggressive retaliation, there is more room for maneuver than is exercised.

It is commonly thought that the U.S. has no choice in both matters, but in fact, it has more leverage than widely believed: Turkey needs U.S. military support against its regional adversaries, Saudi Arabia's economy is dangerously dependent on a single natural resource on which the world is becoming decreasingly reliant, and while China is treated as if it were already the world's largest economy and most powerful military, it is in reality only prospectively so and is facing a multitude of potentially-destabilizing economic, political, and social problems along the way. Combined with an untested military (which last fought in 1979, to dubious success) and an unpredictable North Korea on its border, China wants a war even less than the U.S. does.

Once the international community abandons the illusion that liberal-democratic Confucianism can be found in a CCP-ruled China and that progressive and moderate forms of Islam will emerge in Saudi Arabia or Turkey under its current governance, it can recognize that greater support for Taiwan and Kurdistan not only aligns with its norms but also promotes its longer-term strategic interests.

What that backing would entail requires a more thoroughgoing policy discussion, but there is substantial space between appeasement and starting a war, and the U.S. should be exploring possible "grey zone" activity: gradual, incremental, and subtle series of actions, each of which alone would not warrant an adversarial response, but when taken together significantly alter the geopolitical landscape. This strategy has been skillfully employed by China in building its artificial islands in the South China Sea and by Russia in occupying parts of Ukraine.

Developing a comparable response to counter such aggressions and promote the interests of those the U.S. should be championing is a necessary policy discussion that follows from the realization that these greater powers will not moderate themselves, with or without prodding.

In both cases, the American government should do more than these peoples themselves can ask for-such as official Track 1 discussions with Taiwan, selling it more arms, issuing more forceful statements about American protection for 
Taiwan as a fellow liberal democracy, including Taiwan's representatives in summits of various kinds - because of the nature of the international backlash, such as to the Sept. 2017 independence referendum in Iraqi Kurdistan. (The recent Taiwan Travel Act, unanimously passed by both houses of the U.S. Congress and signed by the president, for example, is a positive development, but it is only as significant or symbolic as its usage, and must be employed in conjunction with an array of diplomatic, economic, and military tools that slowly erode China's coercive monopolization of "legitimate" governance across the Taiwan Strait.) Such actions would speak volumes to the international community in shoring up Taiwan's international position. They would incur China's wrath, but - taking a page from China's playbook in the South China Sea-each individual action would not be so egregious as to provoke a violent reaction, and would eventually add up to a dramatic change in the status quo.

That the Kurds' and Taiwan's progressive models of society are thriving in regions hostile to their way of life is testament to their robustness and importance- far easier for them to simply succumb to the stronger powers. Their values are aligned with America's own and their spread will help bring long-term security. The current strategy of standing aside while China dictates the fate of Taiwan and the region and permitting major Middle Eastern players to alternately exploit and strike the Kurds only promotes the very values and interests that are dangerous to the world.

It is thus in American society's and international interest to stop using Taiwan and the Kurds as surrogates, pawns, and bargaining chips, while offering nothing more than surreptitious or insincere gestures of support. There will be short-term trade-offs, of course, and it is not without significant risk: but especially given how unreliable China, Saudi Arabia, and other dictatorships have already proven themselves to be (e.g., in dealing with crucial security issues such as North Korea and ISIS), the international community must more openly, publicly, and forcefully champion and defend its liberal and progressive allies with more creative regional tactics, for the sake of its own values and strategic interests as much as for theirs.

Yvonne Chiu is a visiting scholar at the Institute for Advanced Study (Princeton, NJ, USA). She directs The Panopticon Foundation, was an assistant professor of politics at The University of Hong Kong, and works on international relations, military affairs, and international law. https:// www.ias.edu/scholars/yvonne-chiu 